Quebec Cooperative Study of Friedreich's Ataxia

\title{
Platelet Taurine Uptake in Spinocerebellar Degeneration
}

\author{
A. FILLA, R. F. BUTTERWORTH, G. GEOFFROY, B. LEMIEUX AND A. BARBEAU
}

SUMMARY: The uptake of ${ }^{14} \mathrm{C}$-taurine was studied in the platelets of 20 ataxic patients and 20 age-matched normat control subjects. No significant differences were found in uptake or kinetics of taurine between the two groups of subjects. If a transport defect in taurine exists in Friedreich's ataxia, it is not present in all tissues. Preliminary indication was obtained in favor of heterogenity of the uptake pattern between ataxic individuals.

RÉSUMÉ: La captation de la taurine $C^{14}$ fut étudiée dans les plaquettes de 20 patients ataxiques et 20 sujets normaux contrôles apparillés pour l'âge. Aucune différence significative ne fut trouvée dans la captation ou dans les caractéristiques cinétiques de la taurine entre les deux groupes de sujets. Ceci indique que s'il existe un défaut dans le transport de la taurine dans l'ataxie de Friedreich, il n'est certainement pas présent dans tous les tissus. Nous avons obtenu quelques indices préliminaires d'une hétérogénéité de la captation entre les individus ataxiques étudiés.

From the Department of Neurobiology, Clinica Research Institute of Montreal; Hôpital SainteJustine; Centre Hospitalier Universitaire de Sherbrooke.

Reprint requests for the complete supplement on Friedreich's ataxia (Phase Two, Part One) to: Dr. André Barbeau, Clinical Research Institute of Montreal, 110 Pine Avenue West, Montreal, Quebec, Canada H2W IR7.

\section{INTRODUCTION}

Platelets appear to be a model for uptake and binding systems in serotoninergic (Stacey, 1961; Pletscher, 1968; Pletscher et al., 1971; Meynert et al., 1968) and dopaminergic (Boullin, 1970) nerve endings in the brain and sympathetic nerve endings in the periphery (Abrams, 1969; Paasonen, 1973). This evidence has prompted studies of the monoamine and enzymatic content of platelets in several neurological disorders known to have alterations in biogenic amines in the brain, like endogenous depression (Baldessarini, 1972), phenylketonuria (Pare, 1959), Down's syndrome (Lott, 1972), schizophrenia (Murphy et al., 1972; Wyatt et al., 1973; Buchsbaum et al., 1976), Huntington's chorea (Butterworth et al, 1977) and Parkinson's disease (Boullin et al., 1970; Yamaguchi et al., 1972; Barbeau et al., 1975).

Other studies showed that platelets are rich in taurine (Fredo et al., 1959), that the transport of taurine into human platelets is a metabolically dependent process (Ahtee et al., 1974), that the uptake can be suppressed by metabolic inhibitors, structural analogs, putative neurotransmitters and convulsants, and that there is a similarity of taurine uptake by human platelets and rat brain slices (Gaut et al., 1976). These data, according to Gaut and Nauss (1976), suggested that platelets may also serve as model for taurine uptake in the brain. A decreased $V_{\max }$, without change of $\mathrm{K}_{\mathrm{m}}$ and endogenous taurine, has been reported in mongoloid trisomy 21 and mentally retarded patients (Boullin et al:, 1975).

Moreover, taurine seems to be implicated in many of the metabolic abnormalities observed in Friedreich's ataxia (Barbeau, 1976). In patients with this disease and other types of ataxia we found an increase in the urinary excretion of taurine, $\beta$-alanine, and BAIB ( $\beta$-amino-isobutyric acid) with normal plasma levels and with marked increases in the renal clearance rate of taurine (Lemieux et al., 1976). Increased renal clearance rates in the absence of overflow may indicate impaired tubular reabsorption, a membrane transport defect. It has been demonstrated (Scriver and Rosenberg, 1973) that taurine, $\beta$-alanine and BAIB share the same transport system. A specific defect in this system has been described in the mouse (Goldman and Scriver, 1967; Chesney et al., 1975).

It seemed worthwhile to explore the possibility that the renal defect found in the ataxic patients might also be reflected in platelets. If present, it would suggest a generalized defect of uptake and storage of taurine in this disease.

\section{SUBJECTS, MATERIALS AND METHODS}

1) Subjects

a) Controls

Twenty normal volunteer subjects of either sex ranging in age from 20 to 35 years were tested.

\section{b) Patients}

Twenty patients of either sex, ranging from 16 to 49 years, were tested. All were affected with Friedreich's ataxia or with other kinds of ataxia. They were divided into sub-groups according to the classification of Barbeau (1976) (Table 1). Two patients were receiv- 
$\underline{\text { TABLE I }}$

ATAXIC PATIENTS
TABLE 2

PLATELET COUNTS

\begin{tabular}{lccc}
\hline & $\mathrm{N}$ & Mean $\times 10^{3}\left(\mathrm{~nm}^{2}\right)$ & \pm S.E. \\
\hline CONTROLS & 20 & 304.86 & 10.48 \\
PATIENTS & 20 & 311.08 & 13.23 \\
\hline
\end{tabular}

Values are the mean \pm S.E. of the mean ( \pm S.E.)

obtained in the number of subjects indicated (n). ing treatment with insulin because of diabetes.

2) Materials

$\left({ }^{14} \mathrm{C}-1,2\right)$ Taurine, specific activity $56.08 \mathrm{mCi} / \mathrm{mmol}$, was obtained from New England Nuclear Corp., Boston, Mass., U.S.A.

\section{3) Methods \\ a) Preparation of platelets rich plasma}

Blood was collected by venipuncture at 9 a.m. from fasting subjects in $20 \mathrm{ml}$ plastic syringes, each contain- ing $1.5 \mathrm{ml}$ sodium ethylenediaminetetracetic acid (EDTA) solution; $13.5 \mathrm{ml}$ of blood was taken per syringe (final EDTA concentration $0.1 \%$ ). The total blood volume withdrawn was $60 \mathrm{ml}$. Blood was transferred immediately to centrifuge tubes and cooled in ice. Each patient was matched with a control subject done the same day. Tubes were centrifuged $\left(120 \mathrm{~g}, 15\right.$ minutes, $\left.4^{\circ} \mathrm{C}\right)$ to obtain platelet rich plasma. Platelet count was done microscopically in platelet rich plasma. Four counts were performed on each platelet rich sample according to the Rees-Ecker method and the mean value per $\mathrm{mm}^{3}$ used for calculation.

b) Uptake of $\left({ }^{14} \mathrm{C}-1,2\right)$

Taurine by platelets in vitro

One $\mathrm{ml}$ samples of platelet-rich plasma were incubated in an atmosphere of $95 \% \mathrm{O}_{2}$ and $5 \% \mathrm{CO}_{2}$ at $37^{\circ} \mathrm{C}$, using a Dubnoff metabolic incubator (Precision Scientific Co., Chicago). After 10 minutes of preincubation, 1 $\mathrm{n}$ mol of $\left({ }^{14} \mathrm{C}-1,2\right)$ taurine in $10 \mu \mathrm{l}$ of a solution of $0.01 \mathrm{~N} \mathrm{HCI}$ was added to each sample and rapidly mixed

TABIE 4
UPTAKE OF TAURINE BY PLATELEIS

\begin{tabular}{|c|c|c|}
\hline TTME OF IUCUBATTON & $\begin{array}{c}\text { UPTAKE EXPRESSED AS nmol OF }\left({ }^{14} \mathrm{C}-1,2\right) \\
\text { PER } 10^{11} \text { PLATELETS }\end{array}$ & TAURINE \\
\hline (minutes) & $\begin{array}{lc}\text { CONIROLS } & \text { PATIENTS } \\
\text { (mean } \pm \text { S.E.) } & \text { (mean } \pm \text { S.E.) }\end{array}$ & $\bar{P}$ \\
\hline
\end{tabular}

$\begin{array}{rrrl}10 & 4.63 \pm 0.39 & 5.51 \pm 0.42 & p<0.2 \text { N.S. } \\ 30 & 14.77 \pm 0.81 & 14.64 \pm 0.85 & p>0.5 \text { N.s. } \\ 60 & 26.94 \pm 1.49 & 26.00 \pm 1.48 & p>0.5 \text { N.s. } \\ 90 & 36.81 \pm 1.67 & 36.05 \pm 1.65 & p>0.5 \text { N.S. } \\ 120 & 47.51 \pm 2.06 & 47.65 \pm 2.06 & p>0.5 \text { N.S. }\end{array}$

The above results were obtained in experiments with platelets from 20 ataxic and 20 controls incubated with $1 \mu \mathrm{M}$ of $\left({ }^{14} \mathrm{C}-1,2\right)$ taurine for different times.
UPTAKE OF TAURINE IN PATIENTS DIVIDED INTO SUB-GROUPS

\begin{tabular}{lcl}
\hline SUB-GROUPS & UPIAKE AFTER $120 \mathrm{MIN}$ & $\mathrm{P}$ \\
\hline $\mathrm{Ia}+\mathrm{Ib}$ & $47.20 \pm 3.20$ & $\mathrm{p}>0.5$ \\
$\mathrm{Ia}$ & $47.34 \pm 3.54$ & $\mathrm{p}>0.5$ \\
$\mathrm{IIa}+\mathrm{IIb}$ & $48.19 \pm 2.56$ & $\mathrm{p}>0.5$ \\
$\mathrm{IIa}$ & $46.07 \pm 2.68$ & $\mathrm{p}>0.5$ \\
IIb & $55.62 \pm 3.90$ & $\mathrm{P}>0.4$
\end{tabular}

The value are mean \pm S.E. and are expressed as nmol/10 11 platelets after $120 \mathrm{~min}$ of incubation - Student's t-test was used. 
(Vortex Mixer) to give a final $\left.{ }^{14} \mathrm{C}-1,2\right)$ taurine concentration of 1 $\mu \mathrm{M}$. Incubation then was continued for samples of each subject for periods of $10,30,60,90,120$ minutes.

c) Kinetics of uptake of $\left({ }^{14} \mathrm{C}-1,2\right)$ taurine by platelets

$1 \mathrm{n} \mathrm{mol}$ of labelled taurine and different concentrations of cold taurine were added to the samples to give four different final concentrations of taurine: $48 \mu \mathrm{M}, 24 \mu \mathrm{M}, 4.8$ $\mu \mathrm{M}, 2.4 \mu \mathrm{M}$. The incubation was continued for 15 minutes and was then stopped by cooling in ice: Platelets were isolated by centrifugation $\left(20,000 \mathrm{G}, 5\right.$ minutes, $\left.4^{\circ} \mathrm{C}\right)$ and platelet poor plasma was decanted directly into liquid scintillation vials, containing $12 \mathrm{ml}$ of a mixture of Triton $X-100$ and toluene $(1: 2 \mathrm{v} / \mathrm{v})$ containing PPO $8.25 \mathrm{~g}$; dimethyl POPOP $0.25 \mathrm{~g}$, in "scintanalyzed grade" toluene $1,000 \mathrm{ml}$ (Fisher Scientific Co., Ltd). To each platelet pellet was added $1 \mathrm{ml}$ bidistilled water and the platelets were disrupted by sonication (15 seconds, Sonic 300 dismembrator, setting Platelet lysates were transferred to liquid scintillation vials. Platelets and platelet poor plasma radioactivity was determined by liquid scintillation spectometry using a Packard model 3375 Tricarb liquid scintillation counter. Each sample was counted 5 minutes and corrected for machine efficiency.

d) Statistical analysis

Student's t-test was carried out according to Goldstein (1964).

\section{RESULTS}

\section{Platelet counts}

There is no significant difference between controls and ataxic patients (Table 2).

\section{Uptake of taurine by platelets}

When platelets were incubated in plasma containing $\left({ }^{14} \mathrm{C}-1,2\right)$ taurine, substantial accumulation took place, 120 minutes of incubation. We could not find any statistical difference between controls and ataxic patients, power $30 \%$ of the maximum). which did not reach saturation after

\section{TABLE 5}

KTNETICS OF TAURINE UPTAKE BY PLATELETS

$\begin{array}{cc}\mathrm{V}_{\max } & \mathrm{K}_{\mathrm{m}} \\ \text { (nmol } \times 10^{-6} / 15 \mathrm{~min} / 10^{11} \text { platelets) } & \left(\mathrm{M} \times 10^{-5} \text { ) }\right.\end{array}$

$\begin{array}{ccc}\text { CONIROLS } & 0.44 \pm 0.06 & 5.33 \pm 0.74 \\ \text { PATIENIS } & 0.48 \pm 0.09 & 5.12 \pm 0.79 \\ \text { P } & p>0.5 \text { N.S. } & p>0.5 \text { N.S. }\end{array}$

The results (mean \pm S.E.) were obtained using platelets from 20 ataxics and 20 controls. Platelets were incubated with 2.4, $4.8,24,48 \mu \mathrm{M}\left({ }^{14} \mathrm{C}-1,2\right)$ taurine for 15 minutes. $\mathrm{K}_{\mathrm{m}}$ and $\mathrm{v}_{\max }$ were calculated according to the Michaelis-Menten equation used to describe saturable enzyme/substrate interactions. even when we divided them into sub-groups (Tables 3 and 4 ).

Moreover, in the two tested families affected by typical Friedreich's ataxia, we found that all the members from the same family had similar uptakes. All three patients from family 1 were low uptakers $\left(\right.$ mean $=36,52 \mathrm{n} \mathrm{mol} / 10^{11}$ platelets; S.E. \pm 1.4$)$ and all the three members from family 2 were high uptakers (mean $\pm 57.73 \mathrm{n}$ $\mathrm{mol} / 10^{11}$ platelets; S.E. \pm 5.8 ).

\section{Kinetics of uptake of taurine by platelets}

Analyses of the data according to the Lineweaver -Burk method (1934)
KINETICS OF TAURINE UPTAKE IN SUB-GROUPS OF PATILNTS

\begin{tabular}{|c|c|c|c|c|}
\hline SUB-GROUPS & $\begin{array}{c}v_{\max } \\
\text { (mmol } \times 10^{-6} / 15 \min / 10^{11} \text { platelets) } \\
\text { (mean } \pm \text { S.E.) }\end{array}$ & $P$ & $\begin{array}{c}\mathrm{K}_{\mathrm{m}} \\
\left(\mathrm{M} \times 10^{-5}\right) \\
\text { (mean } \pm \text { S.E. })\end{array}$ & $P$ \\
\hline $\mathrm{Ia}+\mathrm{Ib}$ & $0.37 \pm 0.09$ & $p>0.5$ & $3.68 \pm 0.80$ & $p<0.2$ \\
\hline Ia & $0.39 \pm 0.10$ & $p>0.5$ & $3.84 \pm 0.87$ & $p<0.4$ \\
\hline$I I a+I I b$ & $0.59 \pm 0.15$ & $p<0.4$ & $6.87 \pm 1.29$ & $p<0.4$ \\
\hline IIa & $0.48 \pm 0.01$ & $p>0.5$ & $6.07 \pm 0.95$ & $p>0.5$ \\
\hline IIb & $0.97 \pm 0.67$ & $p<0.1$ & $9.65 \pm 5.64$ & $p<0.2$ \\
\hline
\end{tabular}

$v_{\max }$ and $k_{m}$ of each sub-group was compared with the values of the controls and student's t-test calculated. 
indicated that there is no significant difference between controls and ataxic patients, even when we divided them into their clinical subgroups (Tables 5, 6).

\section{DISCUSSION}

Previous studies (Lemieux et al., 1976) have indicated that the urinary excretion and the renal clearance rate of taurine and $\beta$-alanine are markedly elevated in most patients with Friedreich's ataxia. This could be the result of a genetic transport defect in the reuptake of taurine in the proximal tubules of the kidney. Alternatively, the taurine loss could be the secondary manifestation of competition for the same transport system by excessive $\beta$-alanine excretion. Finally, abnormaly elevated secretion of taurine or of $\beta$-alanine from the distal tubule could explain the initial observation. In the latter case, one would expect elevated tissue concentrations of taurine, at least in the kidney.

In order to investigate the first possibility, a genetic transport defect in taurine, we looked at the transport and kinetics of taurine in the platelet, considered a model of brain transport. We found no significant change in platelet taurine uptake or kinetics. This indicates that there is no generalized transport defect for taurine in Friedreich's ataxia. This, of course, does not eliminate the possibility that the defect is localized in the kidney, or in other tissues such as the intestine.

Our studies also offer preliminary evidence for a familial characteristic in uptake of taurine in platelets. High uptake families could be distinguished from low uptake families, with relatively constant patterns between individuals of the same family group. Moreover, repeat determinations of taurine uptake in the same individual over a period of time were remarkedly constant, giving more importance to our finding of interfamily heterogeneity in taurine uptake. This observation may be of importance in the interpretation of the overall role of taurine in the pathogenesis of Friedreich's ataxia (Barbeau, 1976).

\section{ACKNOWLEDGMENTS}

The present studies were supported in part by grants from La Fondation Jeanne Mance de l'Hôtel-Dieu, L'Association Canadienne de l'Ataxie de Friedreich and the Medical Research Council of Canada. The authors would like to thank Miss F. Laviolette for technical assistance, Miss D. Bédard, RN, for help with the patients and Miss S. Gariépy for typing the manuscript. Dr. Filla was the recipient of a Canada Council Fellowship.

\section{REFERENCES}

ABRAMS, W. B. and SALOMON, H. M. (1969). The human platelet as a model for the adrenergic neuron: the uptake and release of norepinephrine. Clin. Pharmacol. Ther., 10, 702-709.

AHTEE, L., BOULLIN, D. J. and PAASONEN, M. K. (1976). Transport of taurine by normal human blood platelets. Br. J. Pharmacol., 52, 245-251.

BALDESSARINI, R. J. (1972). Biogenic amines and behavior. Am. Rev. Med., 23, 343-354.

BARBEAU, A. (1976). Freidreich's ataxia 1976 - An overview. Can. J. Neurol. Sci., 3, 389-397.

BARBEAU, A., CAMPANELla, G., BUTTERWORTH, R. F. and YAMADA, K. (1975). Uptake and efflux of ${ }^{14} \mathrm{C}$-dopamine in platelets: Evidence for a generalized defect in Parkinson's disease. Neurology, 25, 1.9.

BOULLIN, D. J., AIRAKSINEN, E. M. and PAASONEN, M. K. (1975). Platelet taurine in Down's syndrome. Medical Biology, 53, 184-186.

BOULLIN, D. J. and O'BRIEN, R. A. (1970). Accumulation of dopamine by blood platelets from normal subjects and parkinsonian patients under treatment with LDopa. Br. J. Pharmacol., 39, 779-788.

BUCHSBAUM, M. S., COURSEY, R. D. and MURPHY, D. L. (1976). The biochemical high-risk paradigm: Behavioral and familial correlates of low platelets monoamine oxidase activity. Science, 194, 339341.

BUTTERWORTH, R. F., GONCE, M. and BARBEAU, A. (1977). Uptake of dopamine by platelets of Huntington's chorea and Gilles de la Tourette's patient: effect of haloperidol. Can. J. Neurol. Sci., 4, 285-288.

CHESNEY, R. W., SCRIVER, C. R. and MOHYUDDIN, F. (1976). Localization of the membrane defect in transepithelial transport of taurine by parallel studies in vivo and in vitro in hypertaurinuric mice. J. Clin. Invest., 57, 183-193.

FREDO, J., KOJ, A., ZGLICZYNSKI, J. M. (1959). Taurine in human blood platelets. Nature, 183, 685-686.

GAUT, Z. N. and NAUSS, C. B. (1976). Uptake of taurine by human blood platelets: A possible model for brain. In: Taurine, (Ed, Huxtable, R. and Barbeau, A.), Raven Press, New York, pp. 91-98.

GOLDMAN, H. and SCRIVER, C. R. (1967). A transport system in mammalian kidney with preference for $\beta$-amino compounds. Pediat. Res., 1, 212-213.

GOLDSTEIN, A. (1964). Biostatistics New York, The MacMillan Company.

LEMIEUX, B., BARBEAU, A., BERONIADE, V., SHAPCOTT, D., BRETON, G., GEOFFROY, G. and MELANCON, S. (1976). Aminoacid metabolism in Friedreich's Ataxia. Can. J. Neurol. Sci., 3, 373-378.

LOTT, I. T., CHASE, T. N. and MURPHY, D. L. (1972). Down's syndrome: Transport, storage and metabolism of serotonin in platelets. Pediat. Res., 6, 730-735.

MEYERS, K. M., STEVENS, D. R. and PADGELT, G. A. (1974). A platelet serotonin anomaly in the Chediak-Higashi Syndrome. Rev. Comm. Chem. Path. Pharmacol., 7, 375-380.

MEYNERT, E. W. and ISAAC, L. (1968). Uptake and binding of serotonin by the platelets and its granules. In: Advances in Neurology, Raven Press, New York, Vol. 6, pp. 113-122.

MURPHY, G. F., MENDELL, J. R. and ENGEL, W. K. (1973). Serotonin and platelet function in Duchenne muscular dystrophy. Arch. Neurol., 28, 239-242.

MURPHY, D. L. and WYATT, F. J. (1972). Reduced monoamine oxidase activity in blood platelets from schizophrenic patients. Nature, 238, 225-226.

PAASONEN, M. K. (1973). Blood platelets as a model for aminergic neurons. In: Pharmacology and Future of Men, Vol. 4, S. Karger, Basel, pp. 328-342.

PARE, C. M. B., SANDLER, M. and STACEY, R. S. (1959). The relationships between increased 5-hydroxyindole metabolism and mental defect in phenylketonuria. Arch. Dis. Chil., 34, 422-423.

PERRY, T. L. (1976). Hereditary mental depression with taurine deficiency: Further studies, including therapeutic trial of taurine administration. In: Taurine (Huxtable, R. and Barbeau, A., Eds.), Raven Press, New York, pp. 365-374.

PLETSCHER, A. (1968). Metabolism, transfer and storage of 5-hydroxytryptamine in blood platelets. Br. J. Pharmacol., 32, 1-16.

PLETSCHER, A., DA PRADA, M., BERNEIS, K. H., TRANZER, J. P. (1971). New aspects of the storage of 5-hydroxytryptamine in blood platelets. Experientia, 27, 993-1120. 
SCRIVER, C. R., PUESCHEL, S. and DAVIES, E. (1966). Hyper- $\beta$-alaninemia associated with $\beta$-aminoaciduria and $\gamma$-aminobutyricaciduria, somnolence and seizures. N. Engl. J. Med., 274, 636-643.

SCRIVER, C. R. and ROSENBERG, L. E. (Eds.) (1973). Aminoacids metabolism and its disorders. In: Major Problems in Clinical
Pediatrics, Vol. 10, W. B. Saunders Co., Philadelphia, pp. 1-491.

STACEY, R. S. (1961). Uptake of 5-hydroxytryptamine by platelets. Br. J. Pharmacol., 16, 284-295.

WYATT, R. J.. MURPHY, D. L., BELMAKER, R. (1973). Reduced monoamineoxidase activity in platelets: $A$ possible genetic marker for vulnerability to schizophrenia. Science, 179, 916-918.

YAMAGUCHI, K.. TOMASI, L., COTE, L. J. (1972). Serotonin content of platelet enriched plasma in parkinsonian patients prior and during treatment with L-3,4-dihydroxyphenylalanine (L-Dopa). Biochem. Med., $6,210-215$. 